\title{
Effectiveness of Automated Customer Centric Banking Services on Profitability and Performance of Indian Commercial Banks
}

\author{
Dr. Sunita Bishnoi ${ }^{1}$ and Dr. Deepak Kumar ${ }^{2}$ \\ ${ }^{1}$ Associate Professor \\ DAV Institute of Management, \\ NH-3, NIT-3, Faridabad, Haryana, India \\ ${ }^{2}$ Assistant Professor \\ DAV Institute of Management, \\ NH-3, NIT-3, Faridabad, Haryana, India \\ 1bishnoi.sunita@rediff.com, ${ }^{2} 25$ sharmadeepak@gmail.com
}

\begin{abstract}
The banking sector plays a very vital role in the economic development and growth of a country. The effective and efficient banking sector is thus the fundamental requirement for smooth functioning of any economy. In the present study an attempt has been made to assess the technical efficiency and performance of Indian Banking Sector. This study uses DEA approach to estimate the technical efficiency of commercial banks in India over the years 2009-2014. Data Envelopment Analysis (DEA) is widely used in banking sector to measure the efficiency and performance of the banks. The study is based on top 24 Indian commercial banks (6 public, 6 new private, 6 old private and 6 from foreign sector banks). The results of the study indicated that old private sector banks and foreign sector banks were found more efficient than new private sector banks, whereas new private sector banks did not use their IT inputs well. In consideration of scale inefficiency analyzed that foreign sector banks have done well in the field of using their input efficiently than other banks.
\end{abstract}

Key Words: Automated, Technology, Banks, Efficiency, DEA, Effective and Efficient

\section{Introduction}

In past some of the year's banks have invested heavily in technology such as ATMs, Debit and Credit cards, Internet banking, Mobile banking, RTGS/NEFT/ECS, electronic payments, fully computerized branches, database management and CRM software etc. New private sector banks, old private sector banks and foreign banks deployed these newer technologies from the beginning of their operations.

The use of technology has led to a win-win situation for Banks and their customers. The organizations that were quick to adopt technology are reaping rich dividends because they managed to cut costs and streamline their operations. Technology has also enhanced customer satisfaction. With a few clicks of the mouse you can transfer the money from one bank account to another bank account anywhere in the country.

Public sector banks (PSBs) also invested heavily in technology but slowly and gradually because of employees' resistance, slow decision making process and old systems. In Public, new private, old private and foreign sector banks had made heavy investment in IT for anticipating significant development in their performance.

However certain studies indicate that the relationship between investment in IT and improvement in performance is moderated by the level of deployment, use and effectiveness of IT. It means that those banks which have deployed IT efficiently witness more improvement in organization performance than those which failed to do so. This 
necessitates relative measurement of efficiency of deployment of IT in the banks; in order to assess the impact of IT investment on performance of the banks rather than mere IT investment. Having regard to this, the present study aims to compare the efficiency of IT deployment of public sector banks, new private sector banks, old private sector banks and foreign sector banks and then categorize the banks on the basis of efficiency scores obtained.

\section{Review of Literature}

Worldwide, there is craze to measure the technical efficiency of banking system. Number of authors attempted to measure the efficiency of banks in different ways. Some of the significant contributions in this area are discussed below:

Suneja A. and Shweta (2015) conducted a study to examine the performance of public and private sector banks during the period 2008-13. The study was based on twenty ratios of the variables relating to capital adequacy, asset quality, management efficiency, earning quality and liquidity. A sample of top five public and five private sector banks selected for the purpose of the study. Twenty one variables related to CAMEL model are used to achieve the objectives of the study. The study concluded that public sector banks has been giving the considerable protection for the creditors with respect to the regular payment of interest and return of capital while private sector banks has just sufficient capital in meeting the contractual obligations between the banks and its creditors in the event of liquidation. About assets, management efficiency and liquidity position public and private sector banks do not have any significant differences.

Subramanyam T. (2014) conducted a study to investigate a new methodology to evaluate the efficiency of banks. The performance indicator variable NPA has been used to identify the environment of a bank. The overall technical efficiency was decomposed to scale, environmental risk and pure technical efficiency. To achieve the objectives of the study secondary data related to Public sector banks, Private sector banks and foreign sector banks were collected from 2012-13. CCR and BCC model of DEA method were adopted to check the technical efficiency of the banks. The empirical results revealed that public sector banks were affected more from environmental risk inefficiency. The independent sample t-statistic showed that in CCR environment there was high significant difference between all pairs of the banks. In BCC and E-BCC environments, there was no significant difference between public and foreign sector banks. It indicates that, public sector banks were equally performed comparing to foreign sector banks. In scale and environmental risk free environment public and foreign sector banks were worked effectively with the mean efficiency scores $80 \%$ and $82 \%$ respectively. The private sector banks were worked poorly with $49 \%$ mean efficiency. Overall, foreign sector banks were worked effectively in all environments. Public sector banks were also equally functioning after removing the scale and environmental risk from overall technical efficiency.

Gudala C. and Rao N. E.S.V. (2014) conducted a study on 'Performance evaluation and ranking of private sector bank'. The study involved the application of DEA model to assess the efficiency of 13 private sector banks in India during the years 2006-07 to 201112. The objective of research was to evaluate the performance of private sector banks and know how private sector banks were influencing the common man and Indian economy. On the basis of constant return to scale, study found that AXIS bank, City Union Bank ltd., Development Credit Bank 1td., South Indian Bank ltd. and Yes Bank ltd. nearly 38 percent of private sector banks exhibited constant performance throughout the study period. South Indian Bank ltd. and Dhanalakshmi Bank ltd. have stood first rank from the year 2008 to 2012.

Ghosh A., Dey M., Bandyopadhyay G., and Guha B. (2014) investigated the efficiency of Indian banks enlisted with the application of Data Envelopment Analysis (DEA), to estimate the efficiency of the Indian banks using publicly available financial 
data of various different parameters related to the financial health of Indian banks. The researcher applied super efficiency model to measure the most efficient bank over a certain time horizon among all the banks. The study found that City Union Bank Ltd., ICICI Bank Ltd., IDBI Bank Ltd., State Bank of India and State Bank of Travancore have proved to be efficient over all the years as compared to the other banks included in the study. These banks have been able to make the optimal utilization of the input consistently throughout the period. They have been able to convert most of their deposits into loans and investment and have been successful in minimizing their operating cost and investment in fixed assets. Development Credit Bank Ltd., Dhanlaxmi Bank Ltd., Karnataka Bank Ltd., Kotak Mahindra Bank Ltd., Lakshmi Vilas Bank Ltd. and Oriental Bank of Commerce have also fared well over the decade included in the study. Eight banks, namely Allahabad Bank, Central Bank Of India, Dena Bank, ING Vysya Bank Ltd., Punjab National Bank, Union Bank of India, Vijaya Bank and Indian Overseas Bank has not been able to match their competitors in any of the 10 years included in the study. They have not been able to utilize the inputs to their fullest.

Nandkumar and Singh A. (2014) used DEA approach to estimate the technical efficiency of commercial banks in India over the years 2006-2010. The present study considers ten commercial banks as decision making units. Out of these, five are public sector banks and other five are private sector banks i.e. State Bank of India, Punjab National Bank, Canara Bank, Vijaya Bank, Allahabad Bank, HDFC Bank, Axis Bank, ICICI Bank, Yes Bank and Kotak Mahindra Bank. Study considered three inputs which are- deposits, number of employees, operating expenses and the three outputs are investments, other income and advances. In this study the data related to various input and outputs over the period 2006 - 2010 have been taken. The results indicate that deregulation of banking sector has led to an increase in the efficiency of commercial banks in India. Banks like Allahabad bank, Canara bank, Kotak Mahindra bank, ICICI bank and Yes bank are very efficient and show consistency in their performance. On the other hand, the performance of banks like SBI, PNB and HDFC bank have poor performance as efficiency scores was below to satisfactory level. The major factor resulting in the poor performance of these three banks was their huge amount of deposits and operating expenses. Also, the excess number of employees was increased their problems. So, here either these banks possess blocked/non-performing assets or was not able to make a set off between the deposits and advances.

Jayaraman A. R. and Srinivasan M.R. (2014) analyzed the performance of the Indian banks using cost, revenue and profit models of DEA and comes-out with a comprehensive efficiency index for banks, by combing the efficiency scores of various DEA models, using the Shannon entropy. The banks included in present study were sound in terms of total assets, manpower, branch network etc., and they have been ranked based on their performance, which depends on optimal utilization of select variables. In order to measure the degree of agreement between rankings of banks based on three different models, namely cost, revenue and profit model, Kendall's coefficient of concordance have been used. The banks which were operating on the efficient frontier are ranked as 1 under the Shannon method, which includes two public sector banks viz., State Bank of India and IDBI Bank, and three private sector banks viz., ICICI Bank, Indusind Bank and Karnataka Bank. These banks operate on the efficient frontier and optimally use their inputs and outputs i.e. without any slack. The second group of banks which was very close to the efficiency frontier with Shannon index more than 0.98 and ranked between 2 and 5 are: Axis Bank, HDFC Bank, ING Vysya Bank and State Bank of Travancore.

Arora and Kaur G. (2014) conducted a study to measure the extent of technical, pure technical and scale efficiencies of the Indian banks across different ownership categories. The study was carried out across 19 nationalized banks, 15 private sector banks and 10 foreign banks for the period 2011-2012. The selection of private and foreign banks has been based upon their average asset size for the period 2011-12. DEA technique was used 
to evaluate the efficiency scores and it was observed that only 10 out of 44 selected banks were efficient. Out of these efficient banks, three banks are from the nationalized category (Andhra Bank, Indian bank and Punjab National Bank), the other four from private sector (Axis Bank Ltd., ICICI Bank Ltd., Kotak Mahindra Bank Ltd. and Tamilnad Mercantile Bank Ltd.) and remaining three from foreign sector (Bank of America NA, Barclays Bank PLC and The Royal Bank of Scotland).The overall technical efficiency score (OTE) were found least for foreign banks whereas the private sector banks have marginally outperformed the public sector banks. Further, it was observed that efficiency scores did not vary much across public sector, private sector and foreign sector banks. Performance of public sector and private sector banks is almost at par with respect to technical efficiency whereas in the case of foreign banks, there lays scope for improving scale efficiency.

Bodla B.S. and Neeraj (2013) conducted a study to analyze managerial efficiency and profitability of selected banks in India. The efficiency and profitability are measured by using panel data of commercial banks for the period from 2001 to 2012. t-test is used to find significance of difference in the performance between two periods (i.e. 2001-2006 and 2007-2012) and between the performance of public and private sector banks. The study found that both public sector banks and private sector banks have performed satisfactorily during 2001-2012 in terms of profitability and managerial efficiency. However the private sector banks were seen having an edge over their counterpart public sector banks. The Interest Spread in case of private sector banks was found higher than that of public sector banks. Further study brings out that return on long term funds as well as on net worth was found significantly higher in public sector banks than private sector banks.

Gupta M. and Sharma M. (2013) examined the effectiveness of economic value added (EVA) vis-à-vis other performance measure as a better indicator of shareholders wealth maximisation of private sector banks in India. The results obtained from analysis was carried out on the secondary financial data from year ended 2003 to 2008 for top 20 private sector banks selected on the basis of highest market capitalisation. The result indicated that EVA does not prove to be better predictor of wealth maximisation as compared to traditional measures in explaining market value added (MVA).

Parsad B. G. V. and Veena D. (2013) study was intended to find out the comparative performance of Indian banks and analyzed that all SCBs have shown significant differences in their performance with reference to return on assets, return on investment, net interest margin, interest spread, operating expenses, non interest income and non performing assets, capital adequacy ratio. Foreign sector banks, new private sector banks are performing better than public sector banks and old private sector banks. While new private sector banks and foreign sector banks started with clean slate and latest technologies. The public sector banks and old private sector banks had to overcome the old system and employee's resistance and introduce the new systems and process and norms.

Kumbhar V. M. (2012) tried to analyze the work performance of the various banks in India with the base of data provided by the reserve bank of India in his various annual reports on Indian banking. According to the available data the foreign banks were performed well, who was on first rank in the manner of operational efficiency, private banks were on second rank and public sector banks were in third rank in India.

Uppal R.K. (2011) analysed the performance of major banks in terms of productivity and profitability in the post e-banking period. To achieve the objectives of the study total nine banks have been selected on the basis of their market share in business in 2003-04, three banks from each group i.e. public sector banks, new private sector banks and foreign sector banks. To analyze the performance of the banks labour productivity ratios, branch productivity ratios and profitability ratios have been calculated. The study investigated that transformation is taking place almost in all categories of banks. IT is playing a crucial 
role to create the drastic changes in the banking industry particularly in the new private sector and foreign sector banks.

Verma A. (2009) conducted a review based study on 'The Impact of Technology on Productivity and Profitability of Indian Banks in Post Liberalization Period' and analyzed that Indian public sector banks have a unique advantage over their competition in terms of their branch network and the large customer base, but in the use of technology that will enable public sector banks to build on their strength. Foreign banks and the new private sector banks have embraced technology right from their inception and they have better adapted themselves to the change in technology. Whereas the public sector banks and old private sector banks have been slow in keeping pace with the changing technology.

\section{Objectives of the Study}

1. To study the impact of customer centric banking practices on productivity of banking sector in India.

2. To compare effectiveness of technology adoption by public, new private, old private and foreign sector banks

3. To compare the productivity of public, new private, old private and foreign sector banks in India.

\section{Research Methodology}

\subsection{Productivity Analysis of Sampled Banks with the Help of Data Envelopment Analysis (DEA)}

The relationship between investment in IT and improvement in performance is moderated by the level of deployment, use and effectiveness of IT. It means that those banks which have deployed IT efficiently witness more improvement in organization performance than those which failed to do so. To compare the bank's efficiency with respect to IT deployment, data envelopment analysis (DEA) technique has been used. Data envelopment is obtained by solving a linear programming model for each decision making unit (DMUs).

DMUs to be analyzed are referred to as the analysis set while every DMU in the reference set appears in the constraint of the linear programming model; the model is solved for each of the units in the analysis set. The DEA-solver software has been used to solve linear programming model. The CCR output oriented model and BCC output oriented model of DEA technique have been utilized to compare the IT efficiency of banks. The DMUs having score of 1 are considered to be efficient while others are rated to be relatively inefficient. DMUs that have a ratio of 1 are referred to as efficient, given the required inputs and produced outputs. The units that have a ratio less than 1 are comparatively less-efficient relative to the more efficient unit(s). Because the weights for input and output variables of DMUs are computed to maximize the ratio and are compared with similar ratios of best performing DMUs hence the measured productivity is referred as relative efficiency (Mittal R. K. and Dhingra S. 2007).

\subsection{DEA Model Selection}

One of the main preferences in selecting a DEA model is to decide, whether to use an input orientation or an output-orientation. This is very important to find the differences between input and output orientation and can typically be best understood by considering whether a DMU emphasize on reducing inputs while achieving the same level of output or emphasize on producing more output given the same level of input. 
DEA offers three possible orientations in efficiency analysis:

1. Input-oriented models are models, where DMUs are deemed to produce a given amount of output with the smallest possible amount of input.

2. Output-oriented models are models, where DMUs are deemed to produce the highest possible amount of output with the given amount of input.

3. Base-oriented models are models, where DMUs are deemed to produce the optimal mix of input and output.

\subsection{Research Model}

The study is executed by dividing the public sector banks, new private sector banks, old private sector banks and foreign sector banks in three categories i.e. "most efficient", "moderately efficient" and "less efficient" on the basis of IT efficiency scores, obtained through application of DEA technique.

\section{Efficiency $=$ Weighted Sum of Inputs $/$ Weighted Sum of Outputs}

In order to compare the efficiency of IT deployment of public sector banks, new private sector banks, old private sector banks and foreign sector banks, information technology related parameters are taken as input variables and performance parameters are taken as output variables. Based on the efficiency scores obtained by applying DEA technique, banks have been divided into three categories i.e. "most efficient", "moderately efficient" and "less efficient". Factors constituting IT success model are identified on the basis of in-depth interviews with bank employees, websites of the banks and past studies on the subject.

\subsection{Hypothesis of the Study}

Significant changes in the banking sector have happened after the entry of old private, new private and foreign banks as a result of economic liberalization. Public sector banks (PSBs) under the pressure of competition, have adopted several initiatives including technology as one of them. Reorganization of branches is happening due to introduction of newer channels like ATMs, computerization in banking, credit cards, debit cards, Internet Banking, Mobile banking, RTGS/NEFT/ECS and computer literate employees. This is expected to bring consistent improvement in scale efficiencies. Hypothesis based on the discussion are listed below:

1. Hypothesis-1 (H 1): Level of efficiency achieved through IT deployment varies among the public sector banks, new private sector banks, old private sector banks and foreign sector banks

2. Hypothesis-2 (H 2): Technical efficiency of public sector banks, new private sector banks, old private sector banks and foreign sector banks improves with the deployment of IT over a period of time.

3. Hypothesis -3 (H 3): Scale inefficiency of public sector banks, new private sector banks, old private sector banks and foreign sector banks decreases with the deployment of IT over a period of time. 
Table 1. Process of Applying DEA Methodology

\begin{tabular}{|c|l|}
\hline $\begin{array}{c}\text { Sr. } \\
\text { No }\end{array}$ & Process of Applying DEA \\
\hline 1. & Review of Literature \\
\hline 2. & Identification of Input and output Variables \\
\hline 3. & $\begin{array}{l}\text { Data compilation through secondary sources i.e. RBI Publications and reports, } \\
\text { Database of Indian economy, Prowess database, IBA Bulletins and Key } \\
\text { Statistics Information's, annual reports of all sampled banks }\end{array}$ \\
\hline 4. & $\begin{array}{l}\text { DEA models } \\
\bullet \text { CCR model } \\
\bullet \text { BCC model }\end{array}$ \\
\hline 5. & $\begin{array}{l}\text { Categorization of banks } \\
\bullet \text { Most efficient } \\
\bullet \text { Moderately efficient } \\
\bullet \text { Less efficient }\end{array}$ \\
\hline
\end{tabular}

\subsection{Methodology Implementation}

Selection of inputs and output and number of DMUs is one of the major difficulties in using DEA model. The scope of present study is confined to six banks each from public sector banks, new private sector banks, old private sector banks and foreign sector banks. Selection of banks are made on the basis of highest asset and income hold by public sector banks, new private sector banks, old private sector banks and foreign sector banks during the study period.

Table 2. Input and Output Variables for Application of DEA Model

\begin{tabular}{|l|l|}
\hline Inputs Variables & Output Variables \\
\hline Total Number of ATMs & Business Per Employee (B.P.E.) \\
\hline $\begin{array}{l}\text { Fully Computerized Branches / Core Banking } \\
\text { Solution (CBS) }\end{array}$ & Profit Per Employee (P.P.E.) \\
\hline $\begin{array}{l}\text { Total Outstanding Number of Debit Cards Per } \\
\text { Computerized Branch (CBS) }\end{array}$ & $\begin{array}{l}\text { Business Per Computerized Branches } \\
\text { (B.P.C.B) }\end{array}$ \\
\hline $\begin{array}{l}\text { Total Outstanding Number of Credit Cards Per } \\
\text { Computerized Branch (CBS) }\end{array}$ & \\
\hline $\begin{array}{l}\text { Total Number of Computer Literate/Technical } \\
\text { Employees Per Computerized Branch (CBS) }\end{array}$ & \\
\hline
\end{tabular}

In order to compare IT efficiency and categorization of the banks, the required data (input variables and output variables) for applying DEA technique has been compiled from secondary sources such as RBI trend and progress reports from 2009 to 2014 and Prowess database, a corporate database developed by Center for Monitoring of Indian Economy (CMIE) and database on Indian economy various reports from 2009 to 2014. DEA-Solver software has been used to solve linear programming model. In the application of DEA, inadequacy of data or sample size may impair results.

The DEA is said to be computationally more convenient when the number of DMUs are larger than the total number of inputs and outputs by at least three times (Dyson et al., 2001). In the present study, 24 sampled banks ( 6 form public, 6 from new private, 6 from old private and 6 from foreign sector banks) have been selected, on the basis of highest assets and income holds by banks during the study period, which are more than three times that of number of inputs and outputs. On each year of data, CCR output-oriented model (output maximization) and BCC output-oriented model (output maximization) have 
been applied. Efficiency scores between 0 and 1 have been obtained for every bank and each year.

Table 3. Sampled Banks/Decision Making Units (DMUs) on the Basis of Holding Highest Assets and Income during the Study Period

\begin{tabular}{|c|l|l|l|l|}
\hline \multirow{2}{*}{ Sr. No } & \multicolumn{4}{|c|}{ Sampled Bank/Decision Making Units (DMUs) } \\
\cline { 2 - 5 } & Public Sector Bank & $\begin{array}{l}\text { New Private } \\
\text { Sector Banks }\end{array}$ & $\begin{array}{l}\text { Old Private } \\
\text { Sector Banks }\end{array}$ & Foreign Sector Banks \\
\hline 1 & State Bank of India & ICICI Bank & ING Vysya Bank & Citi Bank N.A. \\
\hline 2 & Punjab National Bank & HDFC Bank & $\begin{array}{l}\text { The The Fereral } \\
\text { Bank }\end{array}$ & $\begin{array}{l}\text { Standard } \\
\text { Bank }\end{array}$ \\
\hline 3 & Bank of Baroda & AXIS Bank & $\begin{array}{l}\text { The Jammu and } \\
\text { Kashmir Bank }\end{array}$ & DBS Bank \\
\hline 4 & Bank of India & Yes Bank & $\begin{array}{l}\text { The South Indian } \\
\text { Bank }\end{array}$ & HSBC Bank \\
\hline 5 & Canara Bank & $\begin{array}{l}\text { Kotak Mahindra } \\
\text { Bank }\end{array}$ & $\begin{array}{l}\text { The Karur Vysya } \\
\text { Bank }\end{array}$ & Deutsche Bank AG \\
\hline 6 & Union Bank of India & Indusind Bank & $\begin{array}{l}\text { The Karnataka } \\
\text { Bank }\end{array}$ & Royal Bank of Scotland \\
\hline
\end{tabular}

Weill (1990) pointed out that a time lag exists between investment made in IT and performance of the organization. Brynjolfsson (1993) also found a time lag of two to four years before the strongest organizational impact of information technology is being felt. Similarly, Hoffman et al., (1994) also observed that full effects of any change are not likely to affect performance for several years. For this reason, to categorize the banks, average of the efficiency scores obtained from CCR output-oriented model of each bank for the period 2009 to 2014 have been computed.

The minimum and maximum average efficiency scores obtained for the period 2009 to 2014 were found 0.27 and 1.0 respectively. The range of efficiency scores i.e., 0.27 to 1.0 has been divided into three intervals to categorize the banks as "most efficient", "moderately efficient" and "less efficient" as shown in Table 4.

Table 4. Range of Efficiency Scores

\begin{tabular}{|c|l|l|}
\hline Sr. No & Categories & $\begin{array}{l}\text { Average Efficiency Score } \\
\text { for the Period 2008-2014 }\end{array}$ \\
\hline 1 & Most Efficient & $>0.75$ to 1.0 \\
\hline 2 & Moderately Efficient & $>0.50$ but $<=0.75$ \\
\hline 3 & Less Efficient & 0.27 o 0.50 \\
\hline
\end{tabular}

\section{Results and Discussion}

\subsection{Outcome of CCR Output Orientation Model}

CCR model works on constant return to scale (CRS) assumption. It assumes that all the DMUs are operating at optimal scale. CCR model output results in measure of efficiency, called technical efficiency (TE), which is affected by scale efficiencies (SE). Therefore results of CCR model reflect the overall efficiency of banks. It is also significant to note that output-oriented efficiency measures address the question: "by how much can output quantities be proportionally increased without altering the input quantities?" The BCC model assumes variable return to scale (VRS) specification, permits the calculation of TE, without the scale efficiencies effects. Technical efficiency obtained from BCC model, without the SE effect is known as pure technical efficiency. CCR output oriented model is 
applied on each year of data for the period between 2008-09 and 2013-14 using the selected input and output variables. The results of the model are presented in the Table 5.

Table 5. DEA Efficiency Score of Banks with CCR Output Orientation Model

\begin{tabular}{|c|c|c|c|c|c|c|c|c|}
\hline $\begin{array}{l}\text { Sr. } \\
\text { No }\end{array}$ & DMUs & $\begin{array}{l}\text { Eff } \\
2008- \\
09\end{array}$ & $\begin{array}{l}\text { Eff } \\
2009- \\
10\end{array}$ & $\begin{array}{l}\text { Eff } \\
2010- \\
11\end{array}$ & $\begin{array}{l}\text { Eff } \\
2011- \\
12\end{array}$ & $\begin{array}{l}\text { Eff } \\
2012- \\
13\end{array}$ & $\begin{array}{l}\text { Eff } \\
2013- \\
14\end{array}$ & $\begin{array}{l}\text { Average } \\
2009- \\
2014\end{array}$ \\
\hline \multicolumn{9}{|c|}{ Public Sector Bank } \\
\hline 1 & State Bank of India & 0.51 & 0.53 & 0.45 & 0.46 & 0.45 & 0.49 & 0.48 \\
\hline 2 & $\begin{array}{l}\text { Punjab National } \\
\text { Bank }\end{array}$ & 0.73 & 0.79 & 0.82 & 0.73 & 0.70 & 0.62 & 0.73 \\
\hline 3 & Bank of Baroda & 1 & 1 & 1 & 1 & 1 & 1 & 1 \\
\hline 4 & Bank of India & 1 & 1 & 1 & 0.96 & 1 & 1 & 0.99 \\
\hline 5 & Canara Bank & 0.80 & 0.92 & 0.86 & 0.92 & 0.83 & 0.77 & 0.85 \\
\hline 6 & $\begin{array}{l}\text { Union Bank of } \\
\text { India }\end{array}$ & 0.97 & 1 & 1 & 0.86 & 0.86 & 0.84 & 0.92 \\
\hline $\begin{array}{l}\text { Ave } \\
+ \text { P } \\
\text { C.B }\end{array}$ & $\begin{array}{l}\text { age of DMUs SBI } \\
\mathrm{JB}+\mathrm{BOB}+\mathrm{BOI}+ \\
+\mathrm{UBI}\end{array}$ & 0.84 & 0.87 & 0.86 & 0.82 & 0.81 & 0.79 & 0.83 \\
\hline \multicolumn{9}{|c|}{ New Private Sector Banks } \\
\hline 7 & ICICI Bank & 0.72 & 0.50 & 0.42 & 0.38 & 0.41 & 0.46 & 0.48 \\
\hline 8 & HDFC Bank & 0.22 & 0.27 & 0.30 & 0.30 & 0.32 & 0.34 & 0.29 \\
\hline 9 & AXIS Bank & 0.64 & 0.63 & 0.64 & 0.61 & 0.56 & 0.56 & 0.61 \\
\hline 10 & Yes Bank & 0.89 & 1 & 1 & 1 & 1 & 1 & 0.98 \\
\hline 11 & $\begin{array}{l}\text { Kotak Mahindra } \\
\text { Bank }\end{array}$ & 0.19 & 0.22 & 0.26 & 0.30 & 0.30 & 0.36 & 0.27 \\
\hline 12 & Indusind Bank & 0.71 & 0.45 & 0.40 & 0.38 & 1 & 0.32 & 0.54 \\
\hline $\begin{array}{l}\text { Ave } \\
\text { ICI } \\
+\quad \text { I } \\
\text { Ind }\end{array}$ & $\begin{array}{l}\text { age of DMUs } \\
\text { I + HDFC + AXIS } \\
\text { ES + KOTAK + } \\
\text { sind Bank }\end{array}$ & 0.56 & 0.51 & 0.50 & 0.49 & 0.60 & 0.51 & 0.53 \\
\hline \multicolumn{9}{|c|}{ Old Private Sector Banks } \\
\hline 13 & ING Vysya Bank & 0.75 & 0.60 & 0.44 & 0.36 & 0.48 & 0.57 & 0.53 \\
\hline 14 & The Federal Bank & 0.91 & 0.85 & 0.81 & 0.98 & 0.99 & 0.98 & 0.92 \\
\hline 15 & $\begin{array}{l}\text { The Jammu and } \\
\text { Kashmir Bank }\end{array}$ & 0.64 & 0.66 & 0.53 & 0.62 & 0.89 & 1 & 0.72 \\
\hline 16 & $\begin{array}{l}\text { The South Indian } \\
\text { Bank }\end{array}$ & 1 & 1 & 1 & 1 & 1 & 1 & 1 \\
\hline 17 & Karur Vysya Bank & 0.93 & 0.84 & 0.75 & 0.75 & 0.74 & 0.83 & 0.81 \\
\hline 18 & $\begin{array}{l}\text { The Karnataka } \\
\text { Bank }\end{array}$ & 1 & 0.90 & 0.67 & 0.83 & 0.99 & 0.92 & 0.89 \\
\hline $\begin{array}{l}\text { Ave } \\
\text { Vyy } \\
\text { Jam } \\
\text { The } \\
\text { Kar } \\
\text { Kar }\end{array}$ & $\begin{array}{l}\text { age of DMUs ING } \\
\text { ya + Federal + } \\
\text { mu and Kashmir + } \\
\text { South Indian + } \\
\text { IrVysya } \\
\text { lataka Bank }\end{array}$ & 0.87 & 0.81 & 0.70 & 0.76 & 0.85 & 0.88 & 0.81 \\
\hline \multicolumn{9}{|c|}{ Foreign Sector Banks } \\
\hline 19 & Citi Bank N.A. & 0.81 & 0.78 & 0.77 & 0.66 & 0.69 & 0.74 & 0.74 \\
\hline 20 & $\begin{array}{l}\text { Standard Chartered } \\
\text { Bank }\end{array}$ & 0.43 & 0.45 & 0.66 & 0.49 & 0.74 & 0.63 & 0.57 \\
\hline
\end{tabular}




\begin{tabular}{|l|l|c|c|c|c|c|c|c|}
\hline 21 & DBS Bank & 1 & 1 & 1 & 1 & 1 & 1 & $\mathbf{1}$ \\
\hline 22 & HSBC Bank & 0.44 & 0.48 & 0.55 & 0.59 & 0.70 & 0.69 & $\mathbf{0 . 5 8}$ \\
\hline 23 & Deutsche Bank AG & 1 & 1 & 1 & 1 & 1 & 1 & $\mathbf{1}$ \\
\hline 24 & $\begin{array}{l}\text { Royal Bank of } \\
\text { Scotland }\end{array}$ & 0.42 & 0.44 & 0.48 & 0.60 & 0.62 & 1 & $\mathbf{0 . 5 9}$ \\
\hline $\begin{array}{l}\text { Average of DMUs Citi } \\
\text { Bank + Standard } \\
\text { Chartered + DBS + } \\
\text { HSBC+Deutsche+ } \\
\text { Royal Bank }\end{array}$ & $\mathbf{0 . 6 8}$ & $\mathbf{0 . 6 9}$ & $\mathbf{0 . 7 4}$ & $\mathbf{0 . 7 2}$ & $\mathbf{0 . 7 9}$ & $\mathbf{0 . 8 4}$ & $\mathbf{0 . 7 5}$ \\
\hline
\end{tabular}

It is observed from the Table that from the year 2009 to 2014, IT efficiencies of the banks vary from 0.22 to 1.00 . Also the average efficiency of each of the public, New Private, old Private and Foreign sector bank for the period 2009 to 2014 varies from 0.27 to 1.0, this bring us to conclude that all the banks are not having the same level of IT efficiency. This supports the Hypothesis H 1 that level of efficiency achieved through IT deployment varies between the public, New Private, old Private and Foreign sector banks. From the Table which represents output of CCR model with output orientation, it is clear that relative efficiency score of the HDFC Bank, Kotak Mahindra Bank, The Jammu and Kashmir Bank, HSBC Banks and Royal Bank of Scotland are the banks which showed continuous improvement between the years 2009 to 2014. This allows us to accept the research Hypothesis H 2 that technical efficiency of Public, New Private, Old Private and Foreign sector banks improves with the deployment of IT over a period of time. To compare the IT efficiency and also to categorize the banks as "most efficient", "moderately efficient" and "less efficient", the average efficiency of each bank, for the period 2009 to 2014 has been computed.

Results of the study reveals that in public sector banks; Bank of Baroda, Bank of India, Canara Bank and Union Bank of India are found to be relatively most efficient in IT deployment as compared to other banks with average efficiency scores such as (1.0), (0.99), (0.85) and (0.92) respectively, while in new private sector banks yes Bank fund most efficient in IT deployment as compared to other banks with average efficiency score (0.98). Further study reveals that in old Private Sector banks; The Federal Bank, The South Indian Bank, Karur Vysya Bank and The Karnataka Bank found relatively most efficient banks considering their efficiency scores (0.92), (1.0), (0.81) and (0.89) respectively as compared to other banks, whereas in foreign sector banks; DBS Bank and Deutsche Bank AG also found the most efficient banks as compared to the other banks with their achieved efficiency scores (1.0) for both. These banks together define the efficient frontier and thus, form the reference set for inefficient banks. These banks have been deployed and used their IT resources well and thus indicating no waste of inputs.

On the other hand State Bank of India, ICICI Bank, HDFC Bank and Kotak Mahindra Bank are found to be most inefficient with efficiency scores of $(0.48),(0.48),(0.29)$ and (0.27) respectively it mean that these banks did not used their IT resources well as indicated by their average efficiency scores obtained for the period 2009 to 2014 are too less.

Further study revealed that Punjab National Bank (0.73), Axis Bank (0.61), Indusind Bank (0.54), ING Vysya Bank (0.53), The Jammu and Kashmir Bank (0.72), Citi Bank N.A. (0.74), Standard Chartered Bank (0.57), HSBC Bank (0.58) and Royal Bank of Scotland (0.59) are the banks which found moderately efficient as their efficiency scores are in between the moderately efficient category.

After discussing the analysis of bank wise efficiency scores based on CCR output oriented model, sector wise average of efficiency scores has been also calculated which describe that efficiency score of Public Sector banks (0.83) is comparatively higher than the efficiency score obtained by old private sector banks $(0.81)$ followed by the efficiency 
score of foreign sector banks (0.75). Here it can be concluded that public sector banks, old private sector banks and foreign sector banks are found more efficient than new private sector banks. Whereas new private sector banks are not using their IT inputs well as reflected their efficiency score $(0.53)$ is not good enough to be more efficient.

The minimum and maximum average efficiency scores obtained for the period 2009 to 2014 are 0.27 and 1.0 respectively. The range of average efficiency scores i.e., 0.27 to 1.0 has been divided into three intervals to categorize the banks as "most efficient", "moderately efficient" and "less efficient". Banks obtaining the average efficiency score between 0.27 and 0.50 are placed in category of "less efficient", those obtaining the average efficiency score greater than 0.50 but less than or equal to 0.75 are kept in the category of "moderately efficient" and those obtained the score of more than 0.75 are placed in the category of "most efficient" banks in IT deployment.

\subsection{Outcome of BCC Output Orientation Model}

In order to find scale inefficiency, management inefficiency or pure technical inefficiency has been obtained by applying BCC model. Pure technical inefficiency (obtained from BCC model) i.e., technical inefficiency devoid of scale effects, is totally under the control of management and results directly due to management errors. Thus it is also called management inefficiency. It occurs when more of each input is used, than is required to produce a given level of output. BCC output oriented model is applied on each year of data for the period between 2009 and 2014 using the selected input and output variables and for this average of efficiency scores on the basis of BCC output oriented model has been calculated from 2009 to 2014. The performance of DMUs is summarized in Table 6.

Table 6. DEA Efficiency Score of Banks with BCC Output Orientation Model

\begin{tabular}{|c|c|c|c|c|c|c|c|c|}
\hline $\begin{array}{l}\text { Sr. } \\
\text { No }\end{array}$ & DMUs & $\begin{array}{l}\text { Eff } \\
2008- \\
09 \\
\end{array}$ & $\begin{array}{l}\text { Eff } \\
2009- \\
10\end{array}$ & $\begin{array}{l}\text { Eff } \\
2010- \\
11\end{array}$ & $\begin{array}{l}\text { Eff } \\
2011- \\
12\end{array}$ & $\begin{array}{l}\text { Eff } \\
2012- \\
13\end{array}$ & $\begin{array}{l}\text { Eff } \\
2013- \\
14\end{array}$ & $\begin{array}{l}\text { Average } \\
\text { 2009- } \\
2014 \\
\end{array}$ \\
\hline \multicolumn{9}{|c|}{ Public Sector Bank } \\
\hline 1 & State Bank of India & 0.54 & 0.56 & 0.47 & 0.50 & 0.52 & 0.51 & 0.52 \\
\hline 2 & $\begin{array}{ll}\text { Punjab } & \text { National } \\
\text { Bank } & \end{array}$ & 0.74 & 0.85 & 0.83 & 0.76 & 0.70 & 0.66 & 0.76 \\
\hline 3 & Bank of Baroda & 1 & 1 & 1 & 1 & 1 & 1 & 1 \\
\hline 4 & Bank of India & 1 & 1 & 1 & 0.96 & 1 & 1 & 0.99 \\
\hline 5 & Canara Bank & 1 & 1 & 0.87 & 0.93 & 0.84 & 0.79 & 0.91 \\
\hline 6 & $\begin{array}{l}\text { Union Bank of } \\
\text { India }\end{array}$ & 1 & 1 & 1 & 1 & 1 & 1 & 1 \\
\hline \multicolumn{2}{|c|}{$\begin{array}{l}\text { Average of DMUs SBI + } \\
\text { PNB + BOB + BOI + } \\
\text { C.B + UBI }\end{array}$} & 0.88 & 0.90 & 0.86 & 0.86 & 0.84 & 0.83 & 0.86 \\
\hline \multicolumn{9}{|c|}{ New Private Sector Banks } \\
\hline 7 & ICICI Bank & 0.86 & .50 & 0.46 & 0.45 & 0.44 & 0.46 & 0.53 \\
\hline 8 & HDFC Bank & 0.27 & 0.29 & 0.32 & 0.32 & 0.38 & 0.34 & 0.32 \\
\hline 9 & AXIS Bank & 0.78 & 0.65 & 0.66 & 0.68 & 0.65 & 0.60 & 0.67 \\
\hline 10 & Yes Bank & 1 & 1 & 1 & 1 & 1 & 1 & 1 \\
\hline 11 & $\begin{array}{l}\text { Kotak Mahindra } \\
\text { Bank }\end{array}$ & 0.21 & 0.22 & 0.37 & 0.33 & 0.32 & 0.39 & 0.31 \\
\hline 12 & Indusind Bank & 0.73 & 0.45 & 0.40 & 0.40 & 1 & 0.37 & 0.56 \\
\hline \multicolumn{2}{|c|}{$\begin{array}{l}\text { Average of DMUs } \\
\text { ICICI + HDFC + AXIS }\end{array}$} & 0.64 & 0.52 & 0.54 & 0.53 & 0.63 & 0.53 & 0.57 \\
\hline
\end{tabular}




\begin{tabular}{|c|c|c|c|c|c|c|c|c|}
\hline \multicolumn{2}{|c|}{$\begin{array}{l}+ \text { YES + KOTAK + } \\
\text { INDUSind Banks }\end{array}$} & & & & & & & \\
\hline \multicolumn{9}{|c|}{ Old Private Sector Banks } \\
\hline 13 & ING Vysya Bank & 1 & 1 & 0.49 & 0.38 & 1 & 1 & 0.81 \\
\hline 14 & The Federal Bank & 1 & 0.88 & 0.91 & 1 & 1 & 1 & 0.97 \\
\hline 15 & $\begin{array}{l}\text { The Jammu and } \\
\text { Kashmir Bank }\end{array}$ & 1 & 1 & 0.60 & 0.69 & 1 & 1 & 0.88 \\
\hline 16 & $\begin{array}{l}\text { The South Indian } \\
\text { Bank }\end{array}$ & 1 & 1 & 1 & 1 & 1 & 1 & 1 \\
\hline 17 & $\begin{array}{l}\text { The Karur Vysya } \\
\text { Bank }\end{array}$ & 1 & 1 & 1 & 1 & 0.82 & 1 & 0.97 \\
\hline 18 & $\begin{array}{l}\text { The Karnataka } \\
\text { Bank }\end{array}$ & 1 & 1 & 1 & 1 & 1 & 1 & 1 \\
\hline $\begin{array}{l}\text { Ave } \\
\text { INC } \\
\text { Jan } \\
\text { The } \\
\text { Kar } \\
\text { Kar }\end{array}$ & $\begin{array}{l}\text { age of DMUs } \\
\text { Vyysya + Federal + } \\
\text { mu and Kashmir + } \\
\text { South Indian + } \\
\text { irVysya } \\
\text { lataka }\end{array}$ & 1.0 & 0.98 & 0.83 & 0.85 & 0.97 & 1 & 0.94 \\
\hline \multicolumn{9}{|c|}{ Foreign Sector Banks } \\
\hline 19 & Citi Bank & 1 & 1 & 1 & 1 & 1 & 1 & $\mathbf{1}$ \\
\hline 20 & $\begin{array}{l}\text { Standard Chartered } \\
\text { Bank }\end{array}$ & 0.63 & 0.58 & 0.70 & 0.57 & 0.75 & 0.67 & 0.65 \\
\hline 21 & DBS Bank & 1 & 1 & 1 & 1 & 1 & 1 & 1 \\
\hline 22 & HSBC Bank & 0.90 & 0.75 & 0.83 & 0.87 & 0.74 & 0.75 & 0.81 \\
\hline 23 & Deutsche Bank AG & 1 & 1 & 1 & 1 & 1 & 1 & 1 \\
\hline 24 & $\begin{array}{l}\text { Royal Bank of } \\
\text { Scotland }\end{array}$ & 0.73 & 0.57 & 0.52 & 1 & 1 & 1 & 0.81 \\
\hline $\begin{array}{l}\text { Ave } \\
\text { Ban } \\
\text { Cha } \\
\text { HSI } \\
\text { Roy }\end{array}$ & $\begin{array}{l}\text { age of DMUs Citi } \\
+\quad \text { Standard } \\
+ \text { tered }+ \text { DBS + } \\
C+\text { Deutsche }+ \\
\text { Bank }\end{array}$ & 0.88 & 0.82 & 0.84 & 0.91 & 0.92 & 0.90 & 0.88 \\
\hline
\end{tabular}

From the Table 6, which represents output of BCC model with output orientation, it is clear that average IT efficiency of the banks remained more or less during the period 2009 to 2014 i.e., 0.99. This implies an inefficiency of 1 percent in handing the IT inputs; similarly if IT efficiency is 0.98 then it implies an inefficiency of 2 percent in handing inputs.

It is very much clear from the table that efficiency scores on the basis of BCC model of with output orientation showed that Punjab National Bank (0.76), Bank of Baroda (1.0), Bank of India (0.99), Canara Bank (0.91), Union Bank of India (1.0), Yes Bank (1.0), ING Vysya Bank (0.81), The Federal Bank (0.97), The Jammu and Kashmir Bank (0.88), The South Indian Bank (1.0), The Karur Vysya Bank (0.97), The Karnataka Bank (1.0), Citi Bank N.A. (1.0), DBS Bank (1.0), HSBC Bank (0.81), Deutsche Bank AG (1.0) and Royal Bank of Scotland (0.81) are found to be comparatively more efficient than other sampled banks.

This indicates that these banks have used their IT resources optimally. The results of CCR model reported above, shows an improvement in average IT efficiency (technical efficiency) during the study period, while BCC model results reported that average IT efficiency (management efficiency) of the banks remained more or less same during the study period. This implies that an improvement in technical efficiency has been due to 
improvement in scale efficiency rather than due to management efficiency or pure technical efficiency. While on the other hand it can be analyzed from the BCC model with output orientation efficiency scores in the table that HDFC Bank (0.32) and Kotak Mahindra Bank (0.31) are found less efficient banks, it implies that these banks does not use their input resources well. Whereas table depicts that State Bank of India (0.52), ICICI Bank (0.53), Axis Bank (0.67), Indusind Bank (0.56) and Standard Chartered Bank $(0.65)$ are found moderately efficient banks as their efficiency scores are in the given limits.

After discussing the analysis of bank wise efficiency scores based on BCC output oriented model, sector wise average of efficiency scores also has been calculated which describe that; average of efficiency score of old private sector banks (0.94) is comparatively higher than the average efficiency score obtained by foreign sector banks (0.88), followed by the average efficiency score of public Sector banks (0.86). Here it can be concluded that old private sector banks, foreign sector banks and Public sector banks were found more efficient than new private sector banks.

\subsection{Scale Inefficiencies Public, New Private, Old Private and Foreign Sector Banks}

Scale efficiency is obtained by dividing the efficiency score obtained from CCR model with the efficiency score of BCC model. The percentage inefficiency is obtained by subtracting the score of scale efficiency from unity and multiplying the result with 100 . The scale inefficiency calculated for the period 2009 to 2014 is shown in Table 7.

Results show that overall average scale inefficiency of public sector banks has reduced from 4.98 percent in the year 2009 to 4.75 percent in the year 2014, whereas overall scale inefficiency of new private sector banks has reduced from 12.67 percent in year 2009 to 4.65 percent in year 2014, followed by overall average scale in efficiency of old Private Sector Banks has reduced from 12.83 percent in year 2009 to 11.67 percent in year 2014 and overall scale in efficiency score of Foreign Sector Banks has also reduced from 24.05 percent in year 2009 to 6.66 percent in year 2014. This supports the Hypothesis H 3 that scale inefficiency of public, new private, old private and foreign sector banks decreases with the deployment of IT over a period of time. This improvement can be attributed to the aggressive deployment of Computerized Branches, ATMs, Credit and Debit Cards, Internet Banking, Mobile Banking, and RTGS/NEFT/ECS etc., during this period.

Table 7. Scale Inefficiency of Public, New Private, Old Private and Foreign Sector Banks

\begin{tabular}{|c|c|c|c|c|c|c|c|c|}
\hline $\begin{array}{l}\text { Sr. } \\
\text { No }\end{array}$ & DMUs & $\begin{array}{l}\text { Ineff. } \\
2008- \\
09\end{array}$ & $\begin{array}{l}\text { Ineff. } \\
2009- \\
10\end{array}$ & $\begin{array}{l}\text { Ineff. } \\
2010- \\
11\end{array}$ & $\begin{array}{l}\text { Ineff. } \\
2011- \\
12 \\
\end{array}$ & $\begin{array}{l}\text { Ineff. } \\
2012- \\
13\end{array}$ & $\begin{array}{l}\text { Ineff. } \\
2013- \\
14\end{array}$ & $\begin{array}{l}\text { Average } \\
\text { 2009- } \\
2014 \\
\end{array}$ \\
\hline \multicolumn{9}{|c|}{ Public Sector Bank } \\
\hline 1 & State Bank of India & 5.55 & 5.36 & 4.25 & 8.0 & 13.46 & 3.92 & 6.76 \\
\hline 2 & $\begin{array}{ll}\text { Punjab National } \\
\text { Bank }\end{array}$ & 1.35 & 7.06 & 1.20 & 3.95 & 0 & 6.06 & 3.27 \\
\hline 3 & Bank of Baroda & 0 & 0 & 0 & 0 & 0 & 0 & $\mathbf{0}$ \\
\hline 4 & Bank of India & 0 & 0 & 0 & 0 & 0 & 0 & $\mathbf{0}$ \\
\hline 5 & Canara Bank & 20 & 8.0 & 1.15 & 1.07 & 1.19 & 2.53 & 5.66 \\
\hline 6 & $\begin{array}{l}\text { Union Bank of } \\
\text { India }\end{array}$ & 3 & 0 & 0 & 14.0 & 14.0 & 16.0 & 7.83 \\
\hline \multicolumn{2}{|c|}{$\begin{array}{l}\text { Average of DMUs SBI + } \\
\text { PNB + BOB + BOI + } \\
\text { C.B + UBI }\end{array}$} & 4.98 & 3.40 & 1.1 & 4.50 & 4.78 & 4.75 & 3.92 \\
\hline \multicolumn{9}{|c|}{ New Private Sector Banks } \\
\hline 7 & ICICI Bank & 16.28 & 0 & 8.69 & 15.55 & 6.81 & 0 & 7.89 \\
\hline
\end{tabular}




\begin{tabular}{|c|c|c|c|c|c|c|c|c|}
\hline 8 & HDFC Bank & 18.52 & 6.90 & 6.25 & 9.37 & 15.79 & 0 & 9.47 \\
\hline 9 & AXIS Bank & 17.95 & 3.08 & 3.03 & 10.29 & 13.85 & 6.67 & 9.145 \\
\hline 10 & Yes Bank & 11.0 & 0 & 0 & 0 & 0 & 0 & 1.83 \\
\hline 11 & $\begin{array}{l}\text { Kotak Mahindra } \\
\text { Bank }\end{array}$ & 9.52 & 0 & 29.73 & 9.09 & 6.25 & 7.69 & 10.38 \\
\hline 12 & Indusind Bank & 2.74 & 0 & 0 & 5.0 & 0 & 13.51 & 3.54 \\
\hline \multicolumn{2}{|c|}{$\begin{array}{l}\text { Average of DMUs } \\
\text { ICICI + HDFC + AXIS } \\
\text { + YES + KOTAK + } \\
\text { Indusind Banks }\end{array}$} & 12.67 & 1.66 & 7.95 & 8.22 & 7.12 & 4.65 & 7.04 \\
\hline \multicolumn{9}{|c|}{ Old Private Sector Banks } \\
\hline 13 & INGVysya Bank & 25.0 & 40.0 & 10.20 & 5.26 & 52.0 & 43.0 & 29.24 \\
\hline 14 & The Federal Bank & 9.0 & 3.40 & 10.98 & 2.0 & 1.0 & 2.0 & 4.73 \\
\hline 15 & $\begin{array}{l}\text { The Jammu and } \\
\text { Kashmir Bank }\end{array}$ & 36.0 & 34 & 11.67 & 10.14 & 11.0 & 0 & 17.13 \\
\hline 16 & $\begin{array}{l}\text { The South Indian } \\
\text { Bank }\end{array}$ & 0 & 0 & 0 & 0 & 0 & 0 & $\mathbf{0}$ \\
\hline 17 & $\begin{array}{l}\text { The Karur Vysya } \\
\text { Bank }\end{array}$ & 7.0 & 16.0 & 25.0 & 25.0 & 9.75 & 17.0 & 16.62 \\
\hline 18 & $\begin{array}{l}\text { The Karnataka } \\
\text { Bank }\end{array}$ & 0 & 10.0 & 33.0 & 17.0 & 1.0 & 8.0 & 11.5 \\
\hline $\begin{array}{l}\text { Ave } \\
\text { INC } \\
\text { Jan } \\
\text { The } \\
\text { Ka } \\
\text { Ka }\end{array}$ & $\begin{array}{l}\text { rage of DMUs } \\
\text { Vyysya + Federal + } \\
\text { Imu and Kashmir + } \\
\text { South Indian + } \\
\text { urVysya + } \\
\text { nataka }\end{array}$ & 12.83 & 17.23 & 15.14 & 9.90 & 12.46 & 11.67 & 13.20 \\
\hline \multicolumn{9}{|c|}{ Foreign Sector Banks } \\
\hline 19 & Citi Bank & 19.0 & 22.0 & 23.0 & 34.0 & 31 & 26.0 & 25.83 \\
\hline 20 & $\begin{array}{l}\text { Standard Chartered } \\
\text { Bank }\end{array}$ & 31.75 & 22.41 & 5.71 & 14.03 & 1.33 & 5.97 & 13.53 \\
\hline 21 & DBS Bank & 0 & 0 & 0 & 0 & 0 & 0 & $\mathbf{0}$ \\
\hline 22 & HSBC Bank & 51.11 & 36.0 & 33.73 & 32.18 & 5.40 & 8.0 & 27.74 \\
\hline 23 & Deutsche Bank & 0 & 0 & 0 & 0 & 0 & 0 & $\mathbf{0}$ \\
\hline 24 & $\begin{array}{l}\text { Royal Bank of } \\
\text { Scotland }\end{array}$ & 42.46 & 22.80 & 7.69 & 40.0 & 38.0 & 0 & 25.16 \\
\hline \multicolumn{2}{|c|}{$\begin{array}{l}\text { Average of DMUs Citi } \\
\text { Bank + Standard } \\
\text { Chartered + DBS + } \\
\text { HSBC + Deutsche + } \\
\text { Royal Bank }\end{array}$} & 24.05 & 17.20 & 11.69 & 20.04 & 12.62 & 6.66 & 15.38 \\
\hline
\end{tabular}

Further foreign sector banks and New Private sector Banks have done well in the field of using their input efficiently as their average inefficiency score reduce with much higher rate in comparison to public sector banks and old private sector bank. The exceptionally high inefficiency scores obtained by banks may be due to heavy investment in computerization of banks, ATMs, Credit Cards, Debit Cards, Internet Banking, Mobile Banking applications and RTGS/NEFT/ECS etc., by banks. Results clearly show that banks have used the IT successfully to reduce the scale inefficiency by properly deploying IT inputs Resources. However the almost stagnancy of pure technical efficiency or management efficiency observed in banks by applying BCC model is still an area of concern to the bankers. 
Table 8. Summary of the Support Obtained from the Hypothesis

\begin{tabular}{|c|l|l|}
\hline $\begin{array}{c}\text { Sr. } \\
\text { No }\end{array}$ & Hypothesis & Results \\
\hline 1 & $\begin{array}{l}\text { Hypothesis-1 (H 1): Level of efficiency achieved through IT } \\
\text { deployment varies among the public sector banks, new private } \\
\text { sector banks, old private sector banks and foreign sector banks }\end{array}$ & Supported \\
\hline 2 & $\begin{array}{l}\text { Hypothesis-2 (H 2): Technical efficiency of public sector } \\
\text { banks, new private sector banks, old private sector banks and } \\
\text { foreign sector banks improves with the deployment of IT over a } \\
\text { period of time. }\end{array}$ & Supported \\
\hline 3 & $\begin{array}{l}\text { Hypothesis-3 (H 3): Scale inefficiency of public sector banks, } \\
\text { new private sector banks, old private sector banks and foreign } \\
\text { sector banks decreases with the deployment of IT over a period } \\
\text { of time. }\end{array}$ & Supported \\
\hline
\end{tabular}

\section{Conclusion}

The study has compared the profitability and productivity of the public, old private, new private and foreign sector banks with respect to IT deployment using DEA technique. The CCR and BCC model have been applied on selected input and output variables. Scale inefficiency has also been calculated through CCR and BCC models. On the basis of results provided by CCR model it has been found that public sector banks, old private sector banks and foreign sector banks are found more efficient than new private sector banks, whereas new private sector banks are not using their IT inputs well. In terms of BCC model it has been concluded that old private sector banks, foreign sector banks and public Sector banks were found more efficient than new private sector banks, whereas new private sector banks are not using their IT inputs well.

In terms of scale inefficiency study concluded that foreign sector banks and New Private sector banks have done well in the field of using their input efficiently in comparison to public sector banks and old private sector bank.

\section{References}

[1] Arora and K. Gurpreet, "Evaluating The Efficiency of Indian Banking Industry Using Data Envelope Analysis", 'International Journal of Economics, Commerce and Management', vol. 2, no. 8, (2014), pp. $1-13$

[2] B. S. Bodla and Neeraj, "Managerial Efficiency and Profitability of Banks in India during 2001-2012", 'Research in Business and Management (Academic and Professional Perspective)', Proceeding National Conference, Guru Jambheshwar University of Science and Technology, Hisar, (2013) February 7-8, pp. 576-590.

[3] E. Brynjolfsson, "The Productivity Paradox of Information Technology", "Communications of the ACM', vol. 35, (1993), pp. 66-77.

[4] G. Arijit, D. Munmun, G. Bandyopadhyay and B. Guha, "Technical Efficiency Measurement of Indian Banking companies: An Investigation Using DEA and Super Efficiency Model", 'Lecture Notes on Information Theory', vol. 2, no. 3, (2014) September, pp. 273-288.

[5] G. Chiranjeevi and E. S. V. Rao Narayana, "Performance Evaluation and Ranking of Private Sector Banks using Data Analysis and Super-Efficiency Model", "International Journal of Scientific and Research Publications', vol. 4, no. 12, (2014) December, pp. 1-6.

[6] M. Gupta and M. Sharma, "Evaluating Performance through Wealth Maximization: Evidence from Private Sector Banks", 'Proceedings International Conference on Business and Management, Guru Jambshewar University of Science and Technology', (2013) February, pp. 555-568.

[7] J. J. Hoffman, N. M. Carter and J. B. Cullen, "The Effect of Lag-Structure Identification When Testing for Fit”, 'Organization Studies', vol. 15, no. 6, (1994), pp. 829-848.

[8] A. R. Jayaraman and M. R. Srinivasan, "Performance Evaluation of Banks in India - A Shannon-DEA Approach”, 'Eurasian Journal of Business and Economics', vol. 7, no. 13, (2014), pp. 51-68. 
[9] K. M. Vijay, "Efficiency of Commercial Banks: A Comparative Study of Commercial Banks in India", ETHOS: A Journal of Research Articles in Management Science and Allied Areas ISSN: 0974 - 6706 Published by Rayat Shikshan Sanstha's, Karmaveer Bhaurao Patil Institute of Management Studies and Research, Satara (KBPIMSR) India, December 2012, 415005, Electronic copy available at: http://ssrn.com/abstract=1755455, (2012).

[10] R. K. Mittal and D. Sanjay, "Assessing the Impact of Computerization on Productivity and Profitability of Indian Banks: An Application of Data Envelopment Analysis”, 'Delhi Business Review', vol. 8, no. 1, (2007) January-June.

[11] Nandkumar and S. Archana, "A Study of Technical Efficiency of Banks in India Using DEA", 'IOSR Journal of Business and Management', vol. 16, no. 9.1, (2014) September, pp. 37-43.

[12] G. V. Parsad Bhavani and D. Veena, "Trends in Indian Banking in the Context of Dynamic International Scenario: A Study of Select Banks" Proceeding's, 'International Conference on Changing Dynamics in Global Village', Journal Symbiosis Centre for Management Studies, Noida, (2013), pp. 296-308.

[13] T. Subramanyam, "An Innovative Method to Measure the Efficiency of Indian Commercial Banks DEA Approach”, 'International Journal of Scientific Research (IJSR)', vol. 3, no. 12, (2014) December, pp. 383-389.

[14] S. Ajay and Shweta, "Efficiency Evaluation of Public and Private Sector Banks: A Comparative Study", 'Strategic Business Excellence', Proceeding National Conference at Kurukshetra Universiy, Kurukshetra, Haryana, (2015) March 21, pp. 92-99.

[15] R. K. Uppal, "E-Age Technology-New Face of Indian Banking Industry: Emerging Challenges and New Potentials", Journal of Science and Development Sciences, vol. 1, no. 3, (2011) April, pp. 115-129.

[16] V. Amitabh, "The Impact of Technology on Productivity and Profitability of Indian Banks in Post Liberalization Period”, 'Abhigyan Quest for Excellence', vol. 27, no. 2, (2009) July-September, pp. 1726.

[17] P. Weill, "Do Computers Pay off”,- ICIT Press, Washington, DC: International Center for Information Technologies, (1990). 